\title{
Peroxidase is involved in Pepper yellow mosaic virus resistance in Capsicum baccatum var. pendulum
}

\author{
L.S.A. Gonçalves ${ }^{1}$, R. Rodrigues ${ }^{1}$, M.S.S. Diz ${ }^{2}$, R.R. Robaina ${ }^{3}$, \\ A.T. do Amaral Júnior ${ }^{1}$, A.O. Carvalho ${ }^{2}$ and V.M. Gomes ${ }^{2}$ \\ ${ }^{1}$ Laboratório de Melhoramento Genético Vegetal, \\ Universidade Estadual do Norte Fluminense Darcy Ribeiro, \\ Campos dos Goytacazes, RJ, Brasil \\ ${ }^{2}$ Laboratório de Fisiologia e Bioquímica de Microorganismos, \\ Universidade Estadual do Norte Fluminense Darcy Ribeiro, \\ Campos dos Goytacazes, RJ, Brasil \\ ${ }^{3}$ Laboratório de Entomologia e Fitopatologia, \\ Universidade Estadual do Norte Fluminense Darcy Ribeiro, \\ Campos dos Goytacazes, RJ, Brasil \\ Corresponding author: L.S.A. Gonçalves \\ E-mail: 1sagrural@yahoo.com.br
}

Genet. Mol. Res. 12 (2): 1411-1420 (2013)

Received January 26, 2012

Accepted November 27, 2012

Published April 26, 2013

DOI http://dx.doi.org/10.4238/2013.April.26.3

ABSTRACT. Pathogenesis-related proteins (PRs) are among the
defense mechanisms of plants that work as an important barrier to
the development of pathogens. These proteins are classified into 17
families according to their amino acid sequences, serology, and/or
biological or enzyme activity. The present study aimed to identify PRs
associated with the pathosystem of Capsicum baccatum var. pendulum:
Pepper yellow mosaic virus (PepYMV). Forty-five-day-old plants from
accession UENF 1624, previously identified as resistant to PepYMV,
were inoculated with the virus. Control and infected leaves were
collected for analysis after $24,48,72$, and 96 h. The inoculated and
control plants were grown in cages covered with anti-aphid screens.
Proteins were extracted from leaf tissue and the presence of $\beta-1,3-$
glucanase, chitinase, peroxidase, and lipid transport protein was verified. 
No difference was observed between the protein pattern of control and infected plants when $\beta$-1,3-glucanase, chitinase, and lipid transport protein were compared. However, increased peroxidase expression was observed in infected plants at 48 and $72 \mathrm{~h}$ after inoculation, indicating that this PR is involved in the response of resistance to PepYMV in $C$. baccatum var. pendulum.

Key words: Pathogenesis-related proteins; Resistance to diseases; Biotic stress; Biochemical mechanisms

\section{INTRODUCTION}

Plants are subject to a number of diseases caused by viruses, bacteria, fungi, and nematodes. These pathogens are responsible for crop losses and may have contributed to hunger and malnutrition of humanity since early agricultural practice. Therefore, disease control through genetic resistance is a major goal of plant breeding, and the association between plants and microorganisms has become the focus of many interdisciplinary studies.

Resistance against diseases is associated with preformed and induced mechanisms (Hammond-Kosack and Jones, 1997). The preformed mechanisms include physical barriers such as papillae, haloes, trichomes, and cuticles, which hinder the penetration of a pathogen in plant tissue, and secondary metabolites such as alkaloids, cyanogenic compounds, phenolics, glucosinolates, and terpenoids, which can prevent pathogen colonization, reproduction, and development. On the other hand, induced defense is a set of responses activated by hosts after pathogens are detected. The activation of these responses in plants depends on the efficiency of hosts in recognizing the presence of pathogens by means of perception and signal transduction (Jones and Dangl, 2006; Van Loon et al., 2006).

Induced resistance is often manifested as a hypersensitivity response, i.e., the death of host cells within hours after contact with the pathogen. Other resistance responses may include structural changes, accumulation of reactive oxygen species, synthesis of secondary metabolites, and the production of a wide variety of defense molecules, including pathogenesis-related proteins (PRs) (Van Loon et al., 2006; Elvira et al., 2008).

PRs were first described in tobacco that expressed hypersensitivity response after infection by tobacco mosaic virus (TMV). Later, it was identified in at least 13 plant families during infection by oomycetes, fungi, bacteria, viruses, viroids, nematodes, or insect attack (Van Loon et al., 2006). These proteins are classified into families according to their amino acid sequences, serological relationships, and/or biological or enzymatic activity (Van Loon and Van Strien, 1999; Van Loon et al., 2006).

Van Loon and Van Strien (1999) initially proposed a nomenclature for PRs, grouping them into 14 classes. The first five classes were observed in tobacco plants infected by TMV, and identified as PR-1, PR-2 ( $\beta$-1,3-glucanase), PR-3, PR-4 (chitinase), and PR-5 (thaumatin-like). Subsequently, other classes of PRs were identified, resulting in a new classification containing 17 groups, namely PR-6 (proteinase inhibitor), PR-7 (endoproteinase), PR-8 (chitinase), PR-9 (peroxidase), PR-10 (ribonuclease-like), PR-11 (chitinase), PR-12 (defensin), PR-13 (thionin), PR-14 (lipid carrier protein), PR-15 (oxalate oxidase), PR-16 (oxalate oxidase-like), and PR-17 (unknown) (Van Loon et al., 2006).

Yellow mosaic, which is caused by the potyvirus Pepper yellow mosaic virus 
(PepYMV), is considered one of the most important diseases for solanaceous crops, such as chili pepper, sweet pepper, and tomato in Brazil (Maciel-Zambolim et al., 2004; Nascimento et al., 2007; Bento et al., 2009). The symptoms caused by PepYMV in Capsicum spp include curling leaves, development of yellowish-green mosaic, general reduction in the size of plants and fruits, and fruit deformation (Carmo et al., 2006).

Genetic resistance is the main form of PepYMV control, which has many advantages, especially regarding economic, ecological, and practical aspects. In Capsicum spp, the primary sources of resistance to PepYMV were found in C. annuum, 'Criollo de Morelos' (monogenic dominant resistance), and C. chinense PI 159236 (monogenic recessive resistance) (Boiteux and Pessoa, 1994). Other sources of resistance to PepYMV were detected in $C$. chinense and $C$. baccatum var. pendulum (Bento et al., 2009). Despite the identification of resistance in different species of Capsicum, the defense mechanisms involved in these resistances remain unclear.

The present study aimed to analyze the induction of PRs, focusing on $\beta$-1,3-glucanase, chitinase, lipid transport proteins (LTPs), and peroxidase in C. baccatum var. pendulum plants, accession UENF 1624, which is resistant to PepYMV.

\section{MATERIAL AND METHODS}

\section{Plant materials}

Seeds of C. baccatum var. pendulum from accession UENF 1624, resistant to PepYMV (Bento et al., 2009), were sown in 128-cell polystyrene trays with a commercial substrate. After the development of two pairs of definitive leaves, 160 seedlings were transferred individually to plastic pots containing a mixture of soil and substrate (2:1). The experiment was conducted in cages covered with anti-aphid screens in a greenhouse.

\section{Inoculation procedure}

Nicotiana debneyi plants infected with isolate 3 of PepYMV were used as the source of inoculum. This isolate was obtained from sweet pepper plants collected in a field of the Igarapé municipality, Minas Gerais State and was donated by Prof. Murilo Zerbini from Universidade Federal de Viçosa. Inoculation was performed via plant extract buffered in $0.05 \mathrm{M}$ potassium phosphate, $\mathrm{pH} 7.2$, containing $0.01 \%$ sodium sulfite using 600 -mesh carborundum abrasive (Truta et al., 2004). The seedlings were inoculated at the stage of three definite leaves. The youngest fully expanded leaves were inoculated. Sixteen seedlings inoculated only with buffer solution and abrasive were used as control. Leaves of seedlings from the control plants and the accession UENF 1624 infected with PepYMV were collected at four different times $(24,48,72$, and $96 \mathrm{~h})$ after inoculation.

\section{Protein extraction and quantification}

The leaves of infected and control seedlings were weighed and then macerated in liquid $\mathrm{N}_{2}$. The macerated material was used for the different extraction methods.

For assays using $\beta$-1,3-glucanase and chitinase, extraction was performed using 20 $\mathrm{mM}$ sodium acetate, $\mathrm{pH} 5.5,1 \%$ polyvinylpolypyrrolidone $(\mathrm{w} / \mathrm{v})$, and $1 \mathrm{mM}$ phenylmethyl- 
sulfonyl fluoride (PMSF) at a ratio of $1 \mathrm{~g}$ fresh weight of leaf for $1 \mathrm{~mL}$ buffer, which remained in agitation in microtubes for $60 \mathrm{~min}$ at $4^{\circ} \mathrm{C}$. Then, the material was centrifuged at $10,000 \mathrm{~g}$ at $4^{\circ} \mathrm{C}$ for $20 \mathrm{~min}$. The supernatant was collected and the precipitate was discarded (Caruso et al., 1999; Vieira et al., 2010).

Peroxidase extraction was performed using $10 \mathrm{mM}$ sodium borate, $\mathrm{pH} 9.0,0.125 \mathrm{M}$ $\mathrm{NaCl}$, and $1 \mathrm{mM}$ PMSF at a ratio of $1 \mathrm{~g}$ fresh weight for $4 \mathrm{~mL}$ buffer, which remained under agitation in tubes for $3 \mathrm{~h}$ at $4^{\circ} \mathrm{C}$. The material was centrifuged at $10,000 \mathrm{~g}$ at $4^{\circ} \mathrm{C}$ for $10 \mathrm{~min}$. Next, the supernatant was collected and the pellet discarded. We added $14 \%$ polyethylene glycol and $8.5 \%$ potassium phosphate to the supernatant to separate the pigments. After phase separation, the lower phase was collected (Leon et al., 2002).

The quantitative determinations of proteins were carried out by the Bradford method (1976), using ovalbumin (Sigma, USA) as the standard protein.

\section{Enzyme detection}

Chitinase activity (EC 3.2.1.14) was determined in a Shimadzu spectrofluorometer according to O'Brien and Colwell (1987). The amount of methylumbelliferone released was measured by a primary filter with excitation at $320 \mathrm{~nm}$ and a secondary emission filter at $460 \mathrm{~nm}$. One unit of activity (u.a.) was defined as $1 \mathrm{nmol}$ methylumbelliferone released per minute. Data are reported as u.a. RV (reaction volume)/SV (sample volume) per $\mu \mathrm{g}$ protein $/ \mathrm{mL}$.

The determination of $\beta$-1,3-glucanase activity (EC 3.2.1.39) was performed according to the method described by Fink et al. (1988). One unit of $\beta-1,3$-glucanase activity was defined as the concentration of the enzyme that yields 0.001 absorbance when read at $500 \mathrm{~nm}$ in a spectrophotometer (Shimadzu UVVIS-1203). Data are reported as u.a. RV/SV per $\mu \mathrm{g}$ $\operatorname{protein} / \mathrm{mL}$.

Peroxidase activity (EC 1.11.1.7) was determined by spectrophotometry (Shimadzu UVVIS-1203) according to Leon et al. (2002), with some modifications suggested by Vieira et al. (2010). The enzyme u.a. was defined as the increase of 0.01 in absorbance in the reaction mixture for $3 \mathrm{~min} / \mathrm{mg}$ protein.

\section{Gel electrophoresis}

Gel electrophoresis containing sodium dodecyl sulfate (SDS)-tricine was performed according to Schägger and von Jagow (1987). The SDS polyacrylamide gel electrophoresis (PAGE) was prepared according to Laemmli (1970).

\section{Western blotting}

The extraction of plant tissues for the detection of LTP was performed according to Granier (1988). Polyclonal antibodies produced against purified LTP of Capsicum spp seeds were prepared as described by Diz (2007). After electrophoresis, samples (10 mg crude extract of proteins from infected and uninfected leaves) were transferred to nitrocellulose membranes at 24, 48, 72, and $96 \mathrm{~h}$ after inoculation as described by Towbin et al. (1979). The Western blots were revealed using a chemiluminescence kit (ECL Reagent, Amersham Pharmacia Biotech., USA) according to manufacturer instructions. 


\section{Detection of peroxidase activity on polyacrylamide gel}

Peroxidase activity was detected on $14 \%$ polyacrylamide gel after electrophoresis of leaf tissue extract under non-denaturing conditions. Samples from different extractions containing $40 \mu \mathrm{g}$ protein were mixed with sample buffer without $\beta$-mercaptoethanol and applied on the gel. After the race, the gel was washed three times for $20 \mathrm{~min}$ in $25 \mathrm{~mL} 0.05 \mathrm{M}$ phosphate citrate buffer, $\mathrm{pH} 5.4$, with slow agitation. Peroxidase activity was carried out by soaking the gel in $25 \mathrm{~mL}$ citrate-phosphate buffer, $\mathrm{pH} 5.4$, containing $3 \% \mathrm{H}_{2} \mathrm{O}_{2}$ and $8 \mathrm{~mL}$ guaiacol. After 2 min, brown bands indicated peroxidase activity (Shimoni, 1994).

\section{RESULTS AND DISCUSSION}

The SDS-PAGE gel analysis revealed similar protein profiles for seedlings infected with PepYMV and control at different times after inoculation for the chitinase, $\beta$-1,3-glucanase (Figure 1), and LTP (Figure 2) extractions.

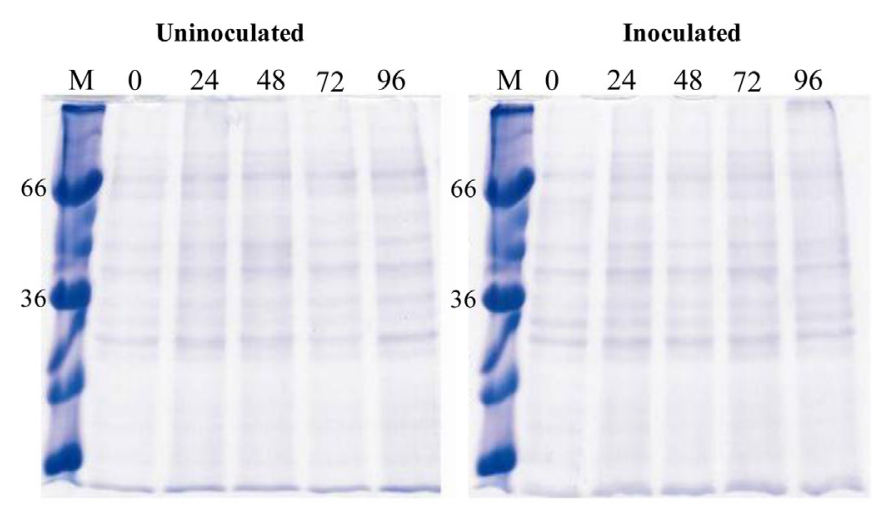

Figure 1. Polyacrylamide gel electrophoresis in $15 \%$ of inoculated and control (non-inoculated) samples extracted for chitinase and glucanase, at different times after inoculation with Pepper yellow mosaic virus $(0,24,48,72$, and $96 \mathrm{~h}$ ) in Capsicum baccatum var. pendulum. Lane $M=$ molecular weight marker in $\mathrm{kDa}$.

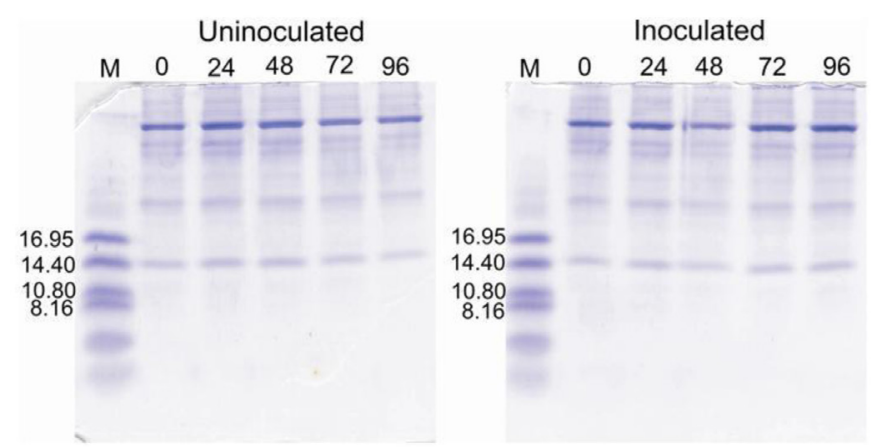

Figure 2. Polyacrylamide-tricine gel electrophoresis of control (non-inoculated) and inoculated samples extracted for lipid transport protein, at different times $(0,24,48,72$, and $96 \mathrm{~h})$ after inoculation with Pepper yellow mosaic virus in Capsicum baccatum var. pendulum. Lane $M=$ molecular weight marker in $\mathrm{kDa}$. 
No chitinase protein activity was observed in infected leaves at different times. Using the same methodology, Vieira et al. (2010) evaluated defense proteins expressed in cowpea seedlings infected by the fungi Fusarium oxysporum $f$. sp phaseoli and $F$. oxysporum $f$. sp ubense, and did not verify chitinase activity after inoculation either. Plant chitinases may be constitutively present or induced after biotic and abiotic stresses. Along with $\beta$-1,3-glucanase, they are directly related to defense against fungi. These enzymes degrade the linear homopolymer $\beta-1,4-\mathrm{N}$-acetylglucosamine, which is an abundant component of fungus cell walls (El-Katatny et al., 2001; Van Loon et al., 2006).

In relation to $\beta$-1,3-glucanase activity and compared to the control, the highest values for activities in the inoculated leaves were observed at 0 and $48 \mathrm{~h}$ after inoculation (Figure 3). Several studies demonstrate a positive correlation between expression of the $\beta$-1,3-glucanase gene and virus invasion (Gorovits et al., 2007; Elvira et al., 2008; Benitez-Alfonso et al., 2010). According to Boevink and Oparka (2005) and Benitez-Alfonso et al. (2010), callose production is regulated by a large family of callose synthases and $\beta$-1,3-glucanase. Thus, the increased induction of glucanase favors callose accumulation and decreased permeability of plasmodesmata, which limits the cell-cell movement of viruses.

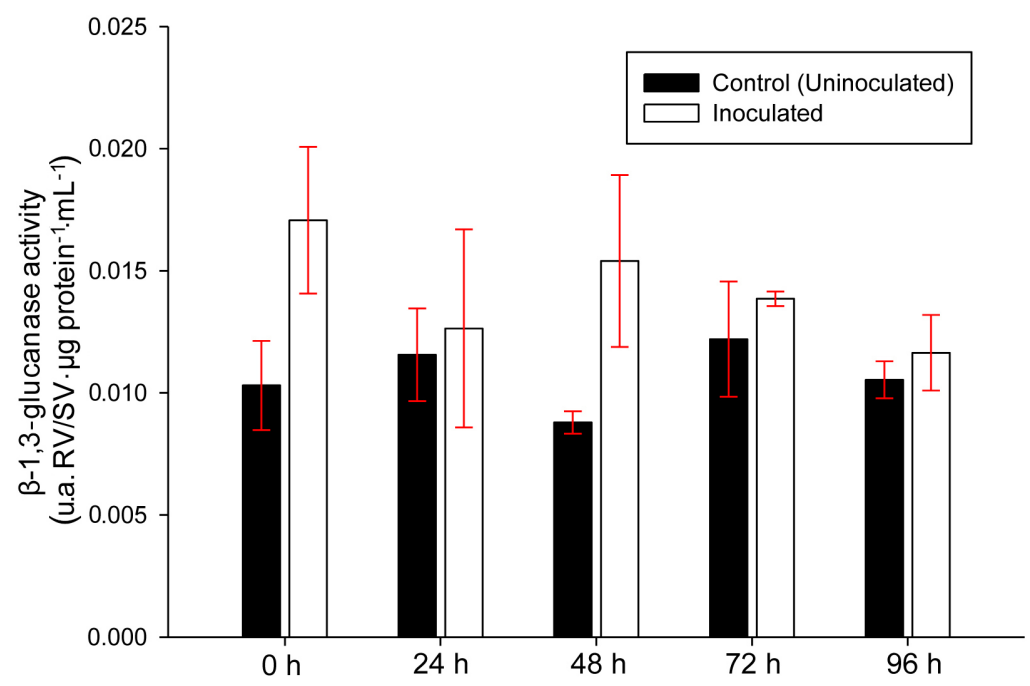

Figure 3. $\beta$-1,3-glucanase activity on leaves of Capsicum baccatum var. pendulum (UENF 1624) non-inoculated and inoculated with Pepper yellow mosaic virus from 0 to $96 \mathrm{~h}$ after inoculation.

It was not possible to detect the presence of LTP in the plant tissues of infected and control seedlings (data not shown). The main function of LTP is to transfer phospholipids between membranes. However, regarding plant defense, several studies have demonstrated that LTPs have antimicrobial activities against in vitro fungi and bacteria (Cammue et al., 1995; Wang et al., 2004). Wang et al. (2004) observed LTP isolates from mung bean seeds exhibiting antifungal activity against $F$. solani, F. oxysporum, Pythium aphanidermatum, and Sclerotium rolfsii, and antibacterial activity against Staphylococcus aureus. Park et al. (2002) found the expression of LTP cDNA in viruses during the response of resistance to TMV in Capsicum, suggesting possible LTP activity in the defense against viruses. 
For peroxidase, analysis of the SDS-PAGE gels (Figure 4A) revealed increased band expression of approximately $45 \mathrm{kDa}$ between 48 and $72 \mathrm{~h}$ after inoculation. Subsequently, peroxidase activity was confirmed at this period on $14 \%$ polyacrylamide gel under non-denaturing conditions, where brown bands determined peroxidase activity (Figure 4B).
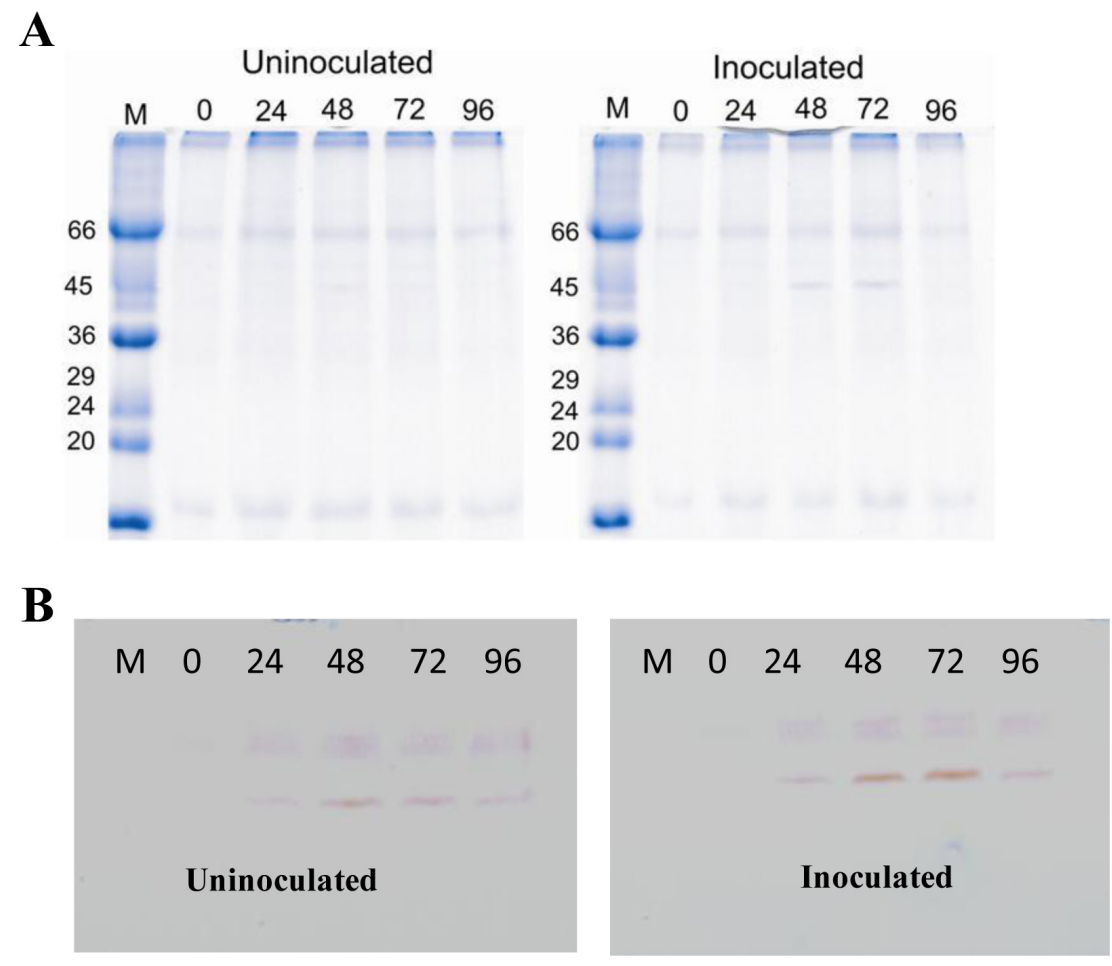

Figure 4. A. Polyacrylamide gel electrophoresis in $15 \%$. B. Peroxidase activity gel electrophoresis of control (uninoculated) and inoculated samples, at different times $(0,24,48,72$, and $96 \mathrm{~h}$ ) after inoculation with Pepper yellow mosaic virus in plants of Capsicum baccatum var. pendulum (UENF 1624). Lane $M=$ molecular weight marker in $\mathrm{kDa}$.

Peroxidase activity was also determined by spectrophotometry (Figure 5), and corroborated the results obtained from the SDS-PAGE and denaturing gels. The inoculated plants demonstrated some peroxidase activity $\left(0.0113\right.$ u.a. $/ \mathrm{t} \cdot \mu \mathrm{g}$ protein $\left.{ }^{-1} \cdot \mathrm{mL}^{-1}\right)$ soon after inoculation, which remained almost constant at $24 \mathrm{~h}$ after inoculation. Increased peroxidase activity was observed at $48 \mathrm{~h}$ after inoculation both for plants inoculated with the virus and for control plants, but greater activity expression was observed in the virus-inoculated plants (Figure 5). The peak of peroxidase activity was observed for inoculated plants $72 \mathrm{~h}$ after inoculation, reaching a value of $0.0453 \mathrm{u}$.a./ $/ \mathrm{\mu g}$ protein ${ }^{-1} \cdot \mathrm{mL}^{-1}$. Peroxidase activity decreased significantly in the inoculated plants $96 \mathrm{~h}$ after inoculation. Thus, there was high peroxidase activity at 48 and $72 \mathrm{~h}$ in the inoculated plants. In the control plants, peroxidase activity was detected from $48 \mathrm{~h}$ after inoculation mimicking buffer solution. 


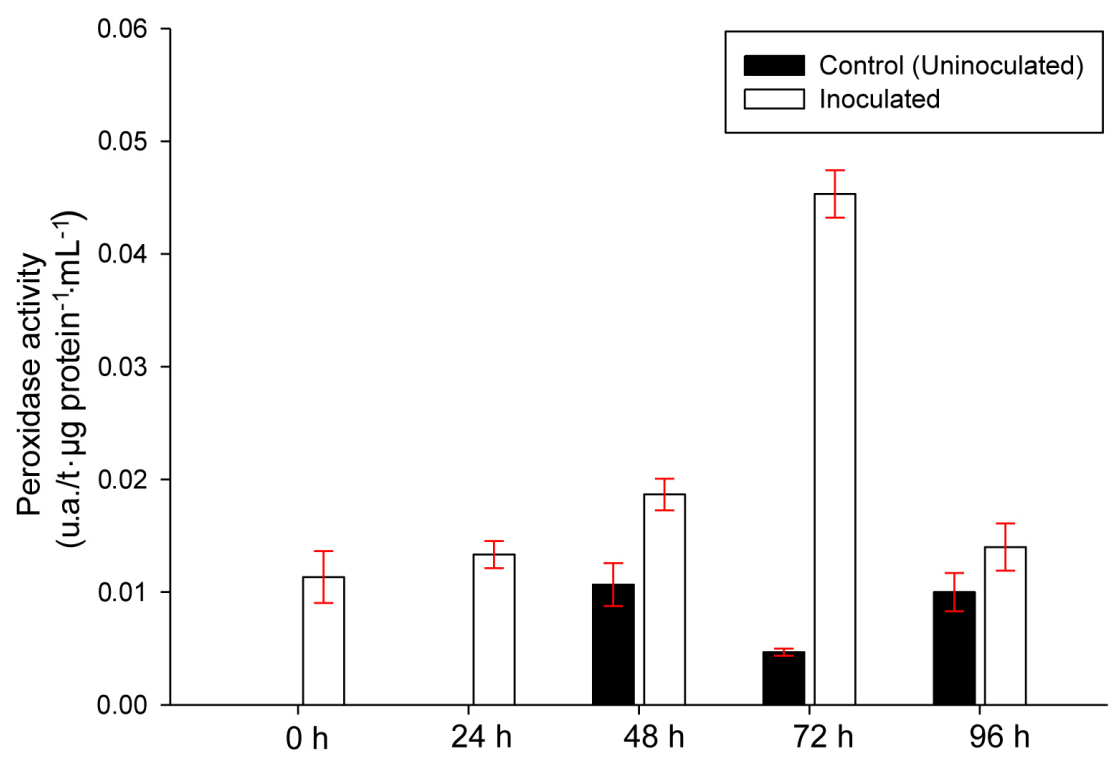

Figure 5. Peroxidase activity in leaves of Capsicum baccatum var. pendulum (UENF 1624) non-inoculated and inoculated with Pepper yellow mosaic virus, from 0 to $96 \mathrm{~h}$.

Peroxidase is an important enzyme in plants that is involved in various reactions such as polysaccharide bonds, indole-3-acetic acid oxidation, monomer bonds, lignification, wound healing, phenol oxidation, defense against pathogens, and regulation of cell elongation, among others (Passardi et al., 2004). Several studies have demonstrated the role of peroxidase in the expression of genes related to defense, cell wall plasticity, and plant cell elongation (Quiroga et al., 2000). Besides the degradation of reactive oxygen species, peroxidases can also generate reactive oxygen species $\left(\mathrm{H}_{2} \mathrm{O}_{2}, \mathrm{OH}^{-}, \mathrm{O}_{2}^{-}\right)$, which are toxic to pathogens and are produced by the oxidative activity of extracellular peroxidase during the strengthening of the cell wall, and by the synthesis of salicylic acid, aromatic monoamines, and chitooligosaccharides (Hiraga et al., 2001; Kawano, 2003; Vieira et al., 2010).

The induction or accumulation of peroxidase in response to pathogen inoculation has been demonstrated in the pathosystems of rice: Pyricularia oryzae and Bipolaris sorokiniana, pumpkin: Colletotrichum lagenarium, and cassava: Xanthomonas axonopodis pv. manihotis (Pereira et al., 2000; Houterman et al., 2007). In plant-virus interactions, peroxidase activity was also associated with tobacco - TMV (Lagrimini and Rothstein, 1987; Ye et al., 1990); in beans White clover mosaic potexvirus (Clarke et al., 2002), and pumpkin - Cucumber mosaic virus and Zucchini yellow mosaic virus (Tecsi et al., 1996; Radwan et al., 2006, 2007).

\section{REFERENCES}

Benitez-Alfonso Y, Faulkner C, Ritzenthaler C and Maule AJ (2010). Plasmodesmata: gateways to local and systemic virus infection. Mol. Plant Microbe Interact. 23: 1403-1412.

Bento CS, Rodrigues R, Zerbini-Júnior FM and Sudré CP (2009). Sources of resistance against the Pepper yellow mosaic virus in chili pepper. Hortic. Bras. 27: 196-201. 
Boevink P and Oparka KJ (2005). Virus-host interactions during movement processes. Plant Physiol. 138: 1815-1821. Boiteux LS and Pessoa HBSV (1994). Additional sources of resistance to an isolates of $\mathrm{PVY}^{\mathrm{m}}$ in Capsicum germoplasm. Fitopatol. Bras. 19: 291.

Bradford MM (1976). A rapid and sensitive method for the quantitation of microgram quantities of protein utilizing the principle of protein-dye binding. Anal. Biochem. 72: 248-254.

Cammue BP, Thevissen K, Hendriks M, Eggermont K, et al. (1995). A potent antimicrobial protein from onion seeds showing sequence homology to plant lipid transfer proteins. Plant Physiol. 109: 445-455.

Carmo MGF, Zerbini-Júnior FM and Maffia LA (2006). Principais doenças da cultura da pimenta. Informe Agropec. 27: 87-98.

Caruso C, Chilosi G, Caporale C, Leonardi L, et al. (1999). Induction of pathogenesis-related proteins in germinating wheat seeds infected with Fusarium culmorum. Plant Sci. 140: 87-97.

Clarke SF, Guy PL, Burritt DJ and Jameson PE (2002). Changes in the activities of antioxidant enzymes in response to virus infection and hormone treatment. Physiol. Plant 114: 157-164.

Diz MSS (2007). Isolamento e Caracterização de uma Proteína Transportadora de Lípideo (LTP) de Pimenta. Master’s thesis, UENF, Campos dos Goytacazes.

El-Katatny MH, Gudelj M, Robra KH, Elnaghy MA, et al. (2001). Characterization of a chitinase and an endo- $\beta-1,3-$ glucanase from Trichoderma harzianum Rifai T24 involved in control of the phytopathogen Sclerotium rolfsii. Appl. Microbiol. Biotechnol. 56: 137-143.

Elvira MI, Galdeano MM, Gilardi P, Garcia-Luque I, et al. (2008). Proteomic analysis of pathogenesis-related proteins (PRs) induced by compatible and incompatible interactions of Pepper mild mottle virus (PMMoV) in Capsicum chinense L3 plants. J. Exp. Bot. 59: 1253-1265.

Fink W, Liefland M and Mendgen K (1988). Chitinases and $\beta$-1,3-glucanases in the apoplastic compartment of oat leaves (Avena sativa L.). Plant Physiol. 88: 270-275.

Gorovits R, Akad F, Beery H, Vidavsky F, et al. (2007). Expression of stress-response proteins upon whitefly-mediated inoculation of Tomato yellow leaf curl virus in susceptible and resistant tomato plants. Mol. Plant Microbe Interact. 20: $1376-1383$.

Granier F (1988). Extraction of plant proteins for two-dimensional electrophoresis. Electrophoresis 9: 712-718.

Hammond-Kosack KE and Jones JD (1997). Plant disease resistance genes. Annu. Rev. Plant Physiol. Plant Mol. Biol. 48: 575-607.

Hiraga S, Sasaki K, Ito H, Ohashi Y, et al. (2001). A large family of class III plant peroxidases. Plant Cell Physiol. 42 : $462-468$.

Houterman PM, Speijer D, Dekker HL, DE Koster CG, et al. (2007). The mixed xylem sap proteome of Fusarium oxysporum-infected tomato plants. Mol. Plant Pathol. 8: 215-221.

Jones JD and Dangl JL (2006). The plant immune system. Nature 444: 323-329.

Kawano T (2003). Roles of the reactive oxygen species-generating peroxidase reactions in plant defense and growth induction. Plant Cell Rep. 21: 829-837.

Laemmli UK (1970). Cleavage of structural proteins during the assembly of the head of bacteriophage T4. Nature 227: 680-685.

Lagrimini LM and Rothstein S (1987). Tissue specificity of tobacco peroxidase isozymes and their induction by wounding and tobacco mosaic virus infection. Plant Physiol. 84: 438-442.

Leon JC, Alpeeva IS, Chubar TA, Galaev IY, et al. (2002). Purification and substrate specificity of peroxidase from sweet potato tubers. Plant Sci. 163: 1011-1019.

Maciel-Zambolim E, Costa H, Capucho AS, Ávila AC, et al. (2004). Surto epidemiológico do vírus do mosaico amarelo do pimentão em tomateiro na região serrana do Espírito Santo. Fitopatol. Bras. 29: 325-327.

Nascimento IR, Costa do Vale LA, Maluf WR, Gonçalves LD, et al. (2007). Reação de híbridos, linhagens e progênies de pimentão a requeima causada por Phytophthora capsici e ao mosaico amarelo causado por Pepper yellow mosaic virus (PepYMV). Ciênc. Agrotec. 31: 121-128.

O'Brien M and Colwell RR (1987). A rapid test for chitinase activity that uses 4-methylumbelliferyl-N-acetyl- $\beta$-Dglucosaminide. Appl. Environ. Microbiol. 53: 1718-1720.

Park CJ, Shin R, Park JM, Lee GJ, et al. (2002). Induction of pepper cDNA encoding a lipid transfer protein during the resistance response to tobacco mosaic virus. Plant Mol. Biol. 48: 243-254.

Passardi F, Penel C and Dunand C (2004). Performing the paradoxical: how plant peroxidases modify the cell wall. Trends Plant Sci. 9: 534-540.

Pereira LF, Goodwin PH and Erickson L (2000). Peroxidase activity during susceptible and resistant interactions between cassava (Manihot esculenta) and Xanthomonas axonopodis pv. manihotis and Xanthomonas cassavae. J. 
Phytopathol. 148: 575-578.

Quiroga M, Guerrero C, Botella MA, Barceló A, et al. (2000). A tomato peroxidase involved in the synthesis of lignin and suberin. Plant Physiol. 122: 1119-1127.

Radwan DEM, Fayez KA, Mahmoud SY, Hamad A, et al. (2006). Salicylic acid alleviates growth inhibition and oxidative stress caused by zucchini yellow mosaic virus infection in Cucurbita pepo leaves. Physiol. Mol. Plant Pathol. 69: 172-181.

Radwan DE, Fayez KA, Mahmoud SY, Hamad A, et al. (2007). Physiological and metabolic changes of Cucurbita pepo leaves in response to Zucchini yellow mosaic virus (ZYMV) infection and salicylic acid treatments. Plant Physiol. Biochem. 45: 480-489.

Schägger H and von Jagow G (1987). Tricine-sodium dodecyl sulfate-polyacrylamide gel electrophoresis for the separation of proteins in the range from 1 to $100 \mathrm{kDa}$. Anal. Biochem. 166: 368-379.

Shimoni M (1994). A method for activity staining of peroxidase and $\beta$-1,3-glucanase isozymes in polyacrylamide electrophoresis gels. Anal. Biochem. 220: 36-38.

Tecsi LI, Smith AM, Maule AJ and Leegood RC (1996). A spatial analysis of physiological changes associated with infection of cotyledons of marrow plants with Cucumber mosaic virus. Plant Physiol. 111: 975-985.

Towbin H, Staehelin T and Gordon J (1979). Electrophoretic transfer of proteins from polyacrylamide gels to nitrocellulose sheets: procedure and some applications. Proc. Natl. Acad. Sci. U. S. A. 76: 4350-4354.

Truta AAC, Souza ARR, Nascimento AVS, Pereira RC, et al. (2004). Identidade e propriedades de isolados de potyvírus provenientes de Capsicum spp. Fitopatol. Bras. 29: 160-168.

Van Loon LC and Van Strien EA (1999). The families of pathogenesis-related proteins, their activities, and comparative analysis of PR1 type proteins. Physiol. Mol. Plant Pathol. 55: 85-97.

Van Loon LC, Rep M and Pieterse CM (2006). Significance of inducible defense-related proteins in infected plants. Annu. Rev. Phytopathol. 44: 135-162.

Vieira FA, Carvalho AO, Vitória AP, Retamal CA, et al. (2010). Differential expression of defence-related proteins in Vigna unguiculata (L. Walp.) seedlings after infection with Fusarium oxysporum. Crop Protect. 29: 440-447.

Wang SY, Wu JH, Ng TB, Ye XY, et al. (2004). A non-specific lipid transfer protein with antifungal and antibacterial activities from the mung bean. Peptides 25: 1235-1242.

Ye XS, Pan SQ and Kué J (1990). Activity, isozyme pattern, and cellular localization of peroxidase as related to systemic resistance of tobacco to blue mold (Peronospora tabacina) and to tobacco mosaic virus. Phytopathology 80: 12951299. 